\title{
Corrosivity of Geothermal Brines Progress Report for Period Ending June 1976
}

\author{
F. A. Posey \\ A. A. Palko
}

\section{OAK RIDGE NATIONAL LABORATORY} OPERATED BY UNION CARBIDE CORPORATION FOR THE ENERGY RESEARCH AND DEVELOPMENT ADMINISTRATION 


\section{DISCLAIMER}

This report was prepared as an account of work sponsored by an agency of the United States Government. Neither the United States Government nor any agency Thereof, nor any of their employees, makes any warranty, express or implied, or assumes any legal liability or responsibility for the accuracy, completeness, or usefulness of any information, apparatus, product, or process disclosed, or represents that its use would not infringe privately owned rights. Reference herein to any specific commercial product, process, or service by trade name, trademark, manufacturer, or otherwise does not necessarily constitute or imply its endorsement, recommendation, or favoring by the United States Government or any agency thereof. The views and opinions of authors expressed herein do not necessarily state or reflect those of the United States Government or any agency thereof. 


\section{DISCLAIMER}

Portions of this document may be illegible in electronic image products. Images are produced from the best available original document. 


\section{Printed in the United States of America. Available from National Technical information Service \\ U.S. Department of Commerce \\ 5285 Port Royal Road, Springfield, Virginia 22161 \\ Price: Printed Copy $\$ 4.00$; Microfiche $\$ 2.25$}

This report was prepared as an account of work sponsored by the United States Government. Neither the United States nor the Energy Research and Development Administration/United States Nuclear Regulatory Commission, nor any of their employees, nor any of their contractors, subcontractors, or their employees, makes any warranty, express or implied, or assumes any legal liability or responsibility for the accuracy, completeness or usefulness of any information, apparatus, product or process disclosed, or represents that its use would not infringe privately owned rights. 
ORNL/TM-5688

Dist. Category UC-4

Contract No. W-7405-eng-26

CHEMISTRY DIVISION

CORROSIVITY OF GEOTHERMAL BRINES

PROGRESS REPORT FOR PERIOD ENDING JUNE 1976

F. A. Posey and A. A. Palko

Date Published: December 1976

NOTICE This document contains information of a preliminary nature. It is subject to revision or correction and therefore does not represent a final report.
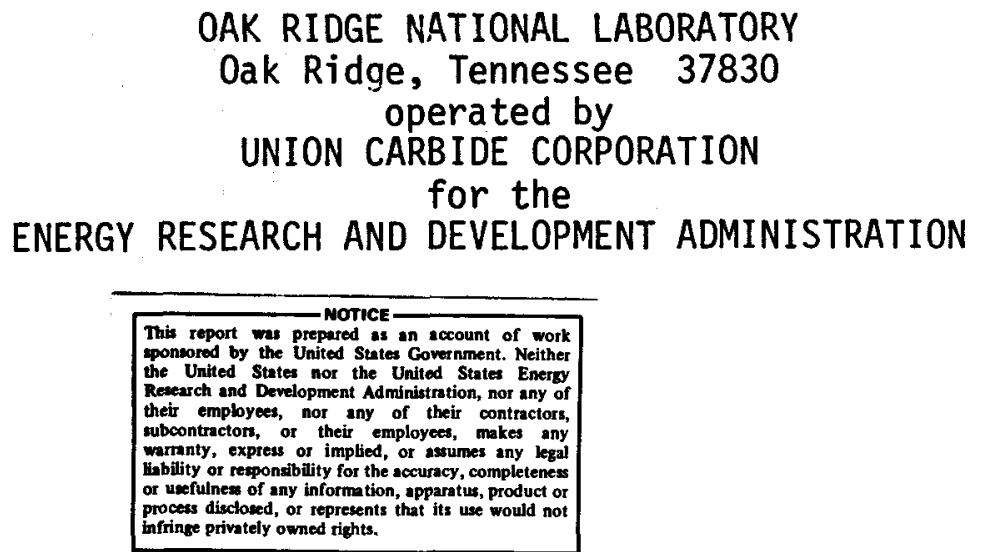


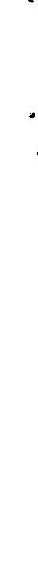




\section{CONTENTS}

Page

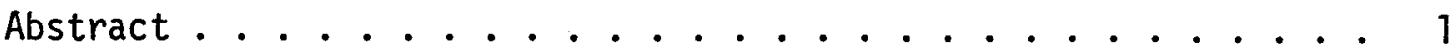

Introduction .................. 1

Experimental Equipment and Procedures for Measurements below $100^{\circ} \mathrm{C}$...................... 4

Corrosion of Iron and Carbon Steel in Deaerated $4 \mathrm{M} \mathrm{NaCl}$

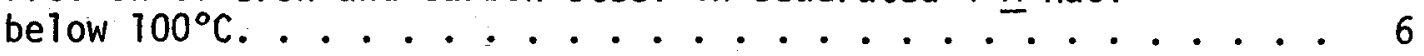

Corrosion Potential as a Function of $\mathrm{pH}$ and Temperature . . 6

Corrosion Rate as a Function of $\mathrm{pH}$ and Temperature. . . . 6

Polarization Curves as a Function of $\mathrm{pH}$......... 9

Reactions of $\mathrm{Fe}$ (II) and $\mathrm{Fe}$ (III) in Deaerated $4 \mathrm{M} \mathrm{NaCl}$ below $100^{\circ} \mathrm{C}$. . . . . . . . . . . . . 11

Reduction of $\mathrm{Fe}(\mathrm{II})$ on Iron ............. 11

0xidation of $\mathrm{Fe}$ (II) and Reduction of $\mathrm{Fe}$ (III) on Pyrolytic Graphite . . . . . . . . . . . . 13

Pitting of 304 Stainless Steel in Synthetic Brine below $100^{\circ} \mathrm{C}$. . 17

Current Transients at Constant Electrode Potential. . . . . 17

Potential Transients at Constant Applied Anodic Current . . . 18

Variation of Pitting Potential with Temperature . . . . . 21

Refreshed, Stirred Titanium Autoclave System for Studies above $100^{\circ} \mathrm{C}$. . . . . . . . . . . . . 21

Research Plans for FYl977. ............... 28

References .................. 31 
CORROSIVITY OF GEOTHERMAL BRINES

PROGRESS REPORT FOR PERIOD ENDING JUNE 1976

F. A. Posey and A. A. Palko

ABSTRACT

Studies carried out during FY1976 on the corrosivity of ferrous materials in synthetic geothermal brines are described. Electrochemical measurements on the spontaneous corrosion potentials and corrosion rates, and on the kinetics of the anodic and cathodic corrosion reactions of iron and carbon steel were made in $4 \mathrm{M} \mathrm{NaCl}$ solution over the $\mathrm{pH}$ range from 1 to 11 at temperatures up to $100^{\circ} \mathrm{C}$ in a conventional Pyrex electrochemical cell. A refreshed, stirred titanium autoclave system was designed, constructed, and tested, and will be used for making electrochemical measurements in synthetic brines up to at least $200^{\circ} \mathrm{C}$. The effect of $\mathrm{pH}$ on hydrolysis, precipitation, and electrochemical reactivity of ferrous and ferric ions in $4 \mathrm{M} \mathrm{NaCl}$ at $25^{\circ} \mathrm{C}$ was studied, and implications for plant operation are discussed. The pitting potential of type 304 stainless steel in synthetic brine was measured as a function of temperature from $25^{\circ}$ to $85^{\circ} \mathrm{C}$. Plans for research on electrochemical aspects of the corrosion of iron and carbon steel in synthetic geothermal brines during FY1977 are presented.

\section{INTRODUCTION}

This report describes work carried out principally during FY1976 on the corrosion of ferrous materials in synthetic geothermal brines. The purpose of these studies, sponsored by the Division of Geothermal Energy of the U. S. Energy Research and Development Administration, is to develop a basic understanding of corrosion processes of ferrous materials in geothermal brines. A quantitative knowledge of the kinetics of corrosion processes in synthetic geothermal brines and the influence of such variables as solution composition and temperature on them will provide a scientific basis for interpretation of field corrosion tests, on-line corrosion measurements, and plant corrosion experience, and perhaps suggest logical means for controlling corrosion during various stages of geothermal plant operation. 
Since both the temperature and concentrations of major and minor components of geothermal brines vary widely from well to well, corrosion data gathered at one location may be of limited value at another, and it is not feasible to conduct corrosion tests under all real or simulated field conditions. Therefore, our approach to research on corrosivity of geothermal brines involves determining how individual components of the brines contribute to the overall corrosion process and how temperature affects the kinetics of corrosion reactions. The rates of corrosion reactions of pure iron, a typical carbon steel, and representative stainless steels are being studied in pure sodium chloride solutions, to which other major and minor brine components may be added, over a chloride concentration range from 0.1 to $4 \underline{\mathrm{M}}$, over the $\mathrm{pH}$ ranae of approximately 3 to 11 , and over a temperature ranae from $25^{\circ}$ to at least $200^{\circ} \mathrm{C}$. From a corrosion standpoint the components of brines that are most likely to affect the kinetics of interfacial reactions, besides chloride concentration and acidity or alkalinity $(\mathrm{pH})$, are carbonate, sulfide, silicate, dissolved oxycen, and perhaps low levels of heavy metal ions which are found in certain natural brines.

The principal experimental approach involves the use of electrochemical techniques to determine the effects of system variables on individual anodic and cathodic processes and on overall corrosion behavior. Indeed, one of the principal advantaaes in the use of electrochemical methods is that they allow studies to be made on the behavior of individual electrode reactions which comprise the overall corrosion process, such as the iron dissolution reaction or the hydrogen evolution reaction. Thus it is possible to determine how the major and minor brine components affect the rates of the individual reactions over a rather wide range of conditions of concentration and temperature. Information of this type is difficult, if not impossible, to obtain by any other method of corrosion research, and should be regarded as complementary to that obtained by other well-established types of corrosion studies.

Some previous studies on corrosion in geothermal brines have been reviewed by Shannon. ${ }^{l}$ However, studies on electrochemical aspects of the corrosion of ferrous materials under geothermal conditions appear to 
be virtually nonexistent. Most reported electrochemical investigations have focussed on the influence of relatively small amounts of chloride ion on active dissolution kinetics of iron and on passivation behavior. ${ }^{2-9}$ A literature review of previous studies on the role of chloride ion in iron corrosion was published by Foley, ${ }^{10}$ while references to the literature on electrochemical aspects of the corrosion of iron in the absence of chloride ions may be found in the work of Lorenz and Eichkorn. 11 Recently, several authors have investigated the kinetics of iron dissolution in concentrated chloride solutions. ${ }^{12-15}$ Different dissolution mechanisms were postulated which indicate that the chloride ion participates directly in the formation of reaction intermediates. Dissolution rate and mechanism were found to depend strongly on chloride ion concentration and $\mathrm{pH},{ }^{15}$ while no significant mass transfer effects were observed in these studies which were performed at relatively low current densities. On the other hand, mass-transport-controlled rates of corrosion of iron in concentrated chloride solutions at the high anodic current densities used in electrochemical machining have been investigated by several workers. ${ }^{16-18}$ In addition, nearly all the reported electrochemical work has been restricted to room temperature, so that much remains to be done over the entire temperature range of interest in geothermal systems.

Some of the results of our experiments carried out during FY1976 on electrochemical aspects of the corrosion of ferrous materials in synthetic geothermal brines are presented and discussed below. These studies are naturally and conveniently divided into two related, complementary tasks: studies in the temperature range, $25^{\circ}$ to $100^{\circ} \mathrm{C}$, which are carried out in a conventional Pyrex electrochemical cell, and studies up to at least $200^{\circ} \mathrm{C}$, for which use of a high-temperature, high-pressure autoclave system is necessary. Much of this work has been concerned with establishment of a baseline of data for the electrochemical kinetics of corrosion of iron and carbon steel in sodium chloride solutions. Other measurements have considered the effect of iron dissolved in the brine as either ferrous or ferric species on reaction kinetics and the influence of $\mathrm{pH}$ on the hydrolysis behavior and reactivity of these ions. Results are presented on the pitting behavior of type 304 austenitic stainless steel in deaerated synthetic brine up to $85^{\circ} \mathrm{C}$. The construction of a refreshed, stirred 
titanium autoclave system for electrochemical measurements at high temperatures and pressures is described. And, finally, plans for continuation of the research during the transition quarter and during FY1977 are outlined briefly.

These studies are a cooperative effort among personnel of the Chemistry Division and the Metals and Ceramics Division at ORNL. The authors are very grateful to J. C. Griess and J. H. DeVan of the Metals and Ceramics Division for their many contributions to both the technical and the administrative aspects of this work.

\section{EXPERIMENTAL EQUIPMENT AND PROCEDURES}

FOR MEASUREMENTS BELOW $100^{\circ} \mathrm{C}$

In the studies carried out below $100^{\circ} \mathrm{C}$, most of the measurements were conducted in a conventional Pyrex cell of approximately $300 \mathrm{ml}$ capacity. A Teflon cell top contained a number of standard taper joints for access to the interior of the cell. The test electrode assembly used a conventional compression-type Teflon seal surrounding a stainless steel or titanium contact rod. Electrodes were cylindrical in shape (diameter = $0.635 \mathrm{~cm}$, length $=1.27 \mathrm{~cm}$ ). Iron electrodes were fabricated from zonerefined iron bar stock (BMI $99.99 \% \mathrm{Fe}$ ), and carbon steel electrodes were machined from type $A 212 B$ steel $(0.358 \% \mathrm{C}, 0.62 \% \mathrm{Mn}, 0.18 \% \mathrm{Si}, 0.033 \% \mathrm{~S}$, $0.012 \% \mathrm{P})$, which is a typical pipeline steel. Stainless steel electrodes were machined from type 304 stock $(18.5 \% \mathrm{Cr}, 9.58 \% \mathrm{Ni}, 0.047 \% \mathrm{C}, 1.22 \% \mathrm{Mn}$, $0.47 \% \mathrm{Si}$ ).

A saturated calomel reference electrode was bridged into the cell from an external vessel with use of a Luggin capillary. The counter electrode was a rod of spectroscopic-grade graphite located in an external vessel and bridged into the test cell by a $U$-tube assembly; this construction prevented reaction products from the counter electrode from diffusing over into the test cell. Stirring was accomplished by use of a Tefloncoated magnetic stirring bar. Temperature control was achieved by means of an integral Pyrex heating jacket which was a part of the cell assembly; water at controlled temperature was circulated through the jacket from an external water bath (Haake Model FK). Solutions within the cell were deaerated by sparging with a stream of fine helium bubbles for at least 
an hour prior to making electrochemical measurements. Facilities were available for continuous monitoring of the $\mathrm{pH}$ of the solution within the cell, display on a digital $\mathrm{pH}$ meter, and recording on a strip chart recorder.

Potential control was accomplished by use of one of several electronic potentiostats, depending upon the type of measurement and upon availability from other experimental work. Some of the early measurements were made with a Princeton Applied Research Corporation Model 170 Electrochemistry System. Later measurements were carried out with a Princeton Applied Research Corporation Model 173 Potentiostat/Galvanostat together with a PAR Model 175 Universal Programmer and a Hewlett-Packard Model 7046A X-Y/Y recorder, or with a Petrolite Potentiodyne Analyzer, Model M-4100. The experimental procedure typically involved establishment of steady-state conditions of electrode potential and corrosion rate, as judged by constancy of polarization resistance measurements, and subsequent measurements of anodic and cathodic polarization curves corresponding to the respective interfacial reactions, usually by use of slow-rate linearsweep voltanmetry (sweep rate $=0.1-1.0 \mathrm{mV} / \mathrm{sec}$ ). The $\mathrm{pH}$ of the solution within the cell was adjusted by manual additions of $\mathrm{HCl}$ or $\mathrm{NaOH}$ stock solutions. Polarization curves were measured as a function of $\mathrm{pH}$ principally in $4 \mathrm{M} \mathrm{NaCl}$ solution (approximately equal to the salinity of some of the brines in the Salton Sea geothermal field) at the temperatures $25^{\circ}, 45^{\circ}$, $65^{\circ}$, and $85^{\circ} \mathrm{C}$. Experiments on the influence of ferrous and ferric ions on reaction rates in the system were carried out by addition of solid reagents $\left(\mathrm{FeSO}_{4} \cdot 7 \mathrm{H}_{2} \mathrm{O}\right.$ or $\left.\mathrm{FeNH}_{4}\left(\mathrm{SO}_{4}\right)_{2} \cdot 12 \mathrm{H}_{2} \mathrm{O}\right)$ directly to the solution within the cell. The data resulting from measurements of this type allow changes in the spontaneous corrosion potential and corrosion rate of iron and steel with changes in $\mathrm{pH}$, chloride ion concentration, and temperature to be interpreted in terms of changes in the rates of the individual anodic and cathodic interfacial reactions, dissolution of iron to form ferrous ions in solution and reduction of water to form molecular hydrogen. 


\section{CORROSION OF IRON AND CARBON STEEL IN

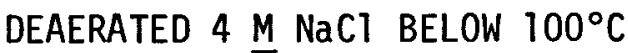

Corrosion Potential as a Function of $\mathrm{pH}$ and Temperature

Some experimental results on the variation of the spontaneous corrosion potential of zone-refined iron and $\mathrm{A} 212 \mathrm{~B}$ carbon steel with $\mathrm{pH}$ in deaerated $4 \underline{\mathrm{M} \mathrm{NaCl}}$ are shown in Fig. 1. Only minor differences between the zone-refined iron and the carbon steel are noted at $25^{\circ} \mathrm{C}$, especially in acid solutions. Three distinct regions of behavior may be seen in these results. In acid solutions, up to about $\mathrm{pH} 4$, the corrosion potential decreases with increasing $\mathrm{pH}$. Simultaneous measurements of the corrosion rate (estimated from polarization resistance) show that, as expected, the spontaneous corrosion rate drops off rapidly in this region with increasing $\mathrm{pH}$. In the region of neutral $\mathrm{pH}^{\prime} \mathrm{s}$, from about $\mathrm{pH} 5$ to 9 at $25^{\circ} \mathrm{C}$, the corrosion potential is independent of pH. 0ther measurements show that the corrosion rate is also constant in this region. Finally, in alkaline solutions the corrosion potential begins to decrease again with increasing $\mathrm{pH}$, although rate measurements do not show much of a decrease in corrosion rate. As shown below, the behavior of the curves in Fig. 1 is understandable on the basis of how the anodic and cathodic polarization curves of the system, and thus the rates of the respective anodic and cathodic reactions, change with $\mathrm{pH}$.

Corrosion Rate as a Function of $\mathrm{pH}$ and Temperature

Results on the variation of the corrosion rate of iron with $\mathrm{pH}$ at $25^{\circ}$ and $85^{\circ} \mathrm{C}$ in deaerated $4 \mathrm{M} \mathrm{NaCl}$ are shown in Fig. 2. The estimated corrosion rates were obtained from measurements of the polarization resistance (or admittance) with use of the equation shown in the body of Fig. 2, where $j_{\text {est }}$ is the estimated corrosion rate $\left(A / \mathrm{cm}^{2}\right), A$ is the surface area of the electrode $\left(\mathrm{cm}^{2}\right), R T / F$ is the thermal volt equivalent $(V)$, and $\partial I / \partial E$ is the polarization admittance (reciprocal of polarization resistance) or the slope of the I - E polarization curve measured at the spontaneous corrosion potential, $E_{\text {corr }}$. More exact estimation of corrosion rates from measurements of polarization admittance (or resistance) requires a knowledge of the slopes of the respective anodic and cathodic polarization 


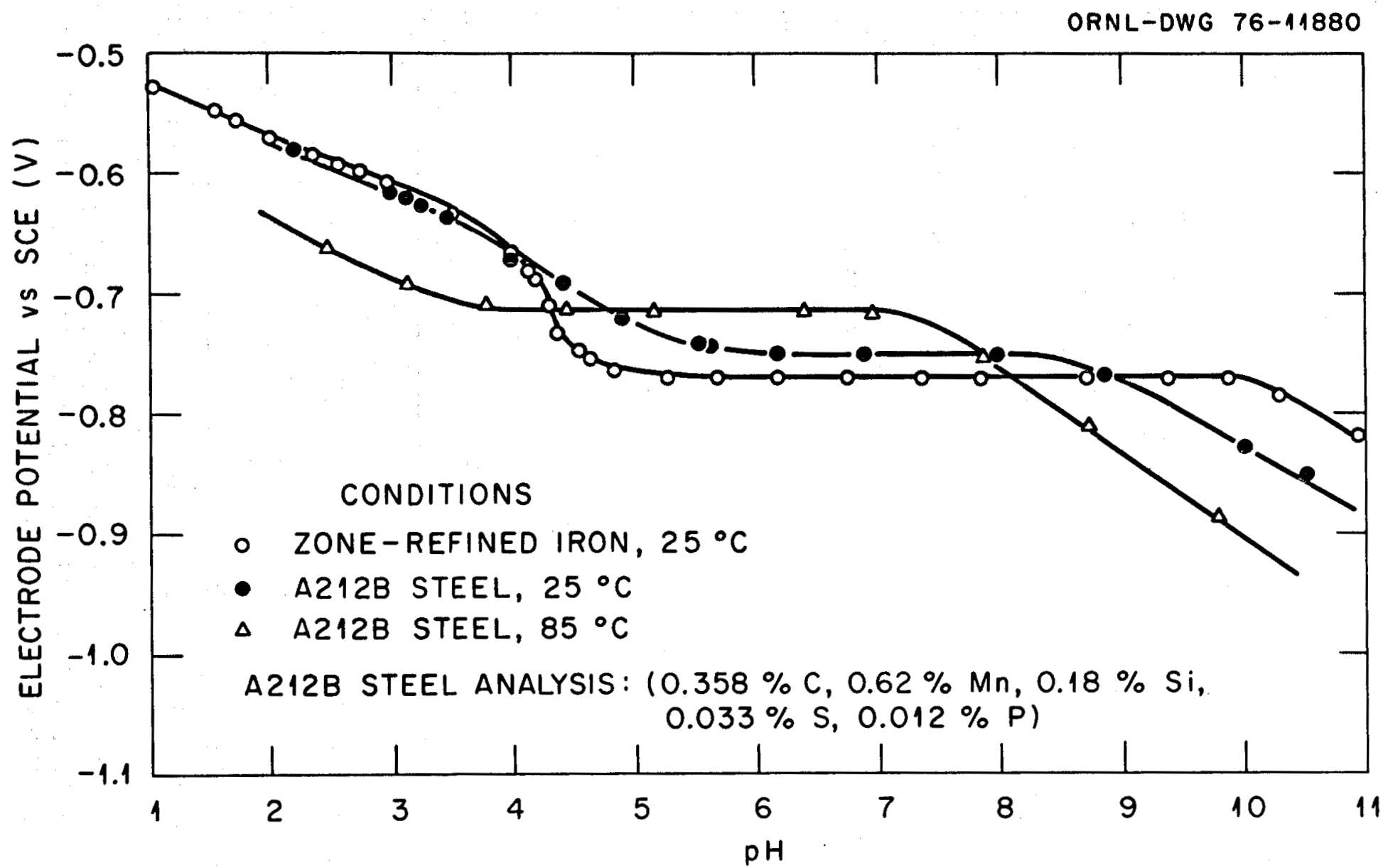

Fig. 1. Corrosion Potential as a Function of $\mathrm{pH}$ for Iron and Steel in Deaerated $4 \mathrm{M} \mathrm{NaCl}$. 


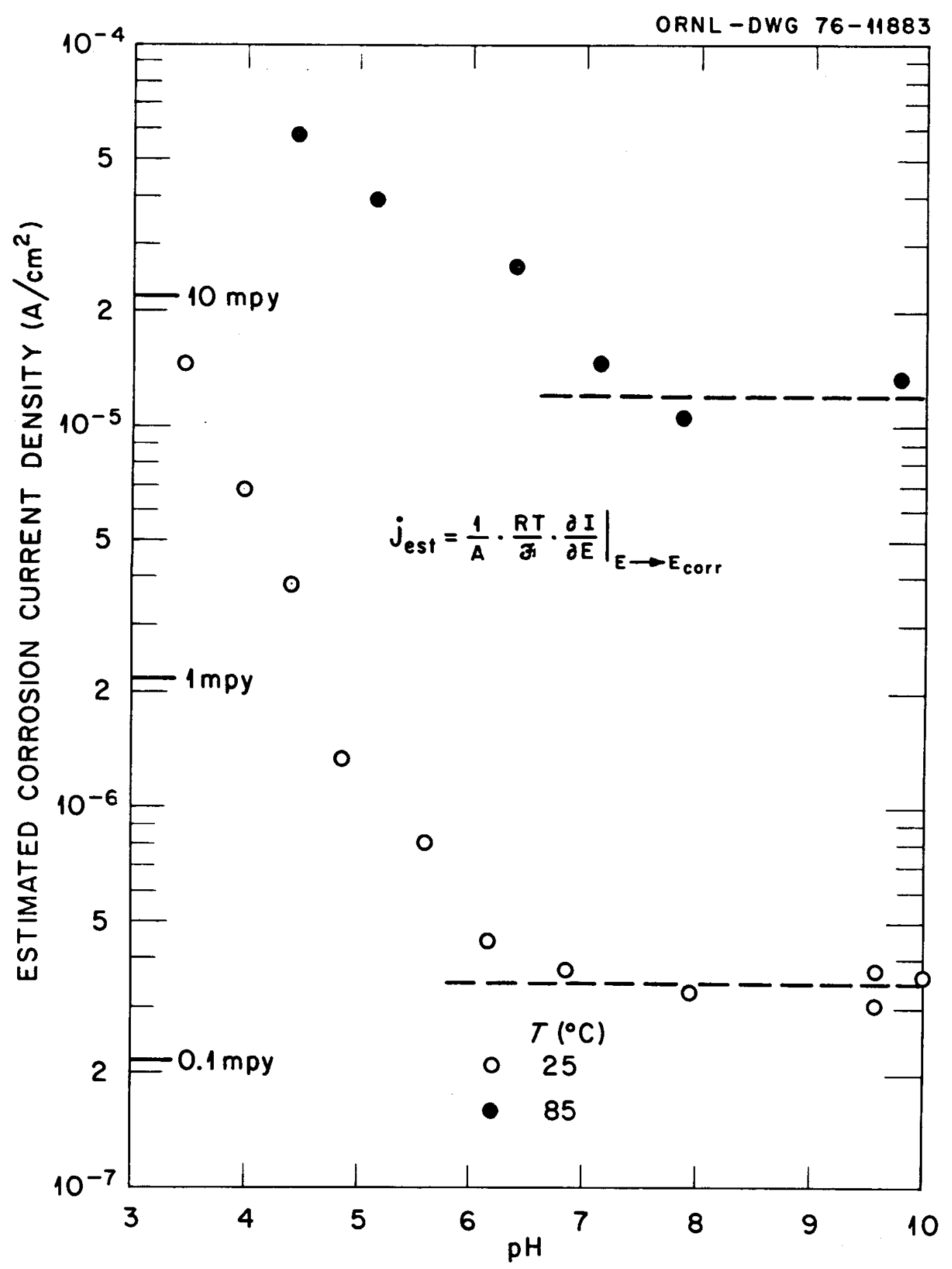

Fig. 2. Effect of pH on Corrosion Rate (Estimated from Polarization Resistance) of Iron in Deaerated $4 \underline{\mathrm{M} \mathrm{NaCl}}$. 
curves and their variation with $\mathrm{pH}$. However, for rapid, semi-quantitative estimation of the change of corrosion rate with some variable, such as $\mathrm{pH}$, use of the relation shown in Fig. 2 is quite adequate. In most cases, corrosion rates are overestimated by this method. The results of Fig. 2 show that, as the $\mathrm{pH}$ decreases in the weakly acidic region, the corrosion rate rises very rapidly. In addition, the influence of temperature on acceleration of the spontaneous corrosion rate is evident.

Polarization Curves as a Function of $\mathrm{pH}$

A set of cathodic polarization curves taken at various $\mathrm{pH}^{\prime} \mathrm{s}$ for the hydrogen evolution reaction on iron in deaerated $4 \mathrm{M} \mathrm{NaCl}$ solution at $25^{\circ} \mathrm{C}$ is shown in Fig. 3. At a pH of 2.5, reduction of hydrogen ions to form molecular hydrogen is observed at the more noble potentials (above approx. $-0.8 \mathrm{~V}$ vs SCE). This is the principal cathodic process in deaerated acid solutions. At lower potentials (approx. -0.9 to $-1.1 \mathrm{~V}$ ) at that $\mathrm{pH}$, there is a limiting current due to the maximum rate of convective diffusion of hydrogen ions to the electrode surface under the prevailing mass transfer conditions. At still lower potentials (below approx. - $1.1 \mathrm{~V}$ ), hydrogen evolution from the solvent water is observed. Under the conditions of these experiments, in which moderate stirring was employed, the rate of the cathodic reaction is under essentially pure activation rate control at the spontaneous corrosion potential (approx. $-0.6 \mathrm{~V}$, cf. Fig. 1). Consequently the corrosion rate and corrosion potential are independent of the velocity of the electrolyte relative to the electrode. However, for stirring rates which are much smaller than those used in these experiments, it is possible for the rate of the cathodic reaction to be determined by the rate of convective diffusion of hydrogen ions to the electrode surface. In such a case the corrosion rate and corrosion potential would be dependent upon the velocity of the electrolyte. A transition region between acid and neutral solution behavior is observed in the corrosion potential $\mathrm{pH}$ relation between $\mathrm{pH} 4$ and 5 at $25^{\circ} \mathrm{C}$ (cf. Fig. 1). This is a region where the hydrogen evolution reaction, reduction of hydrogen ions to form hydrogen, is under mass transport control. As the $\mathrm{pH}$ increases, reduction of hydrogen ions ceases to be an important cathodic process, the evolution of hydrogen comes from the reduction of the solvent water rather than from 


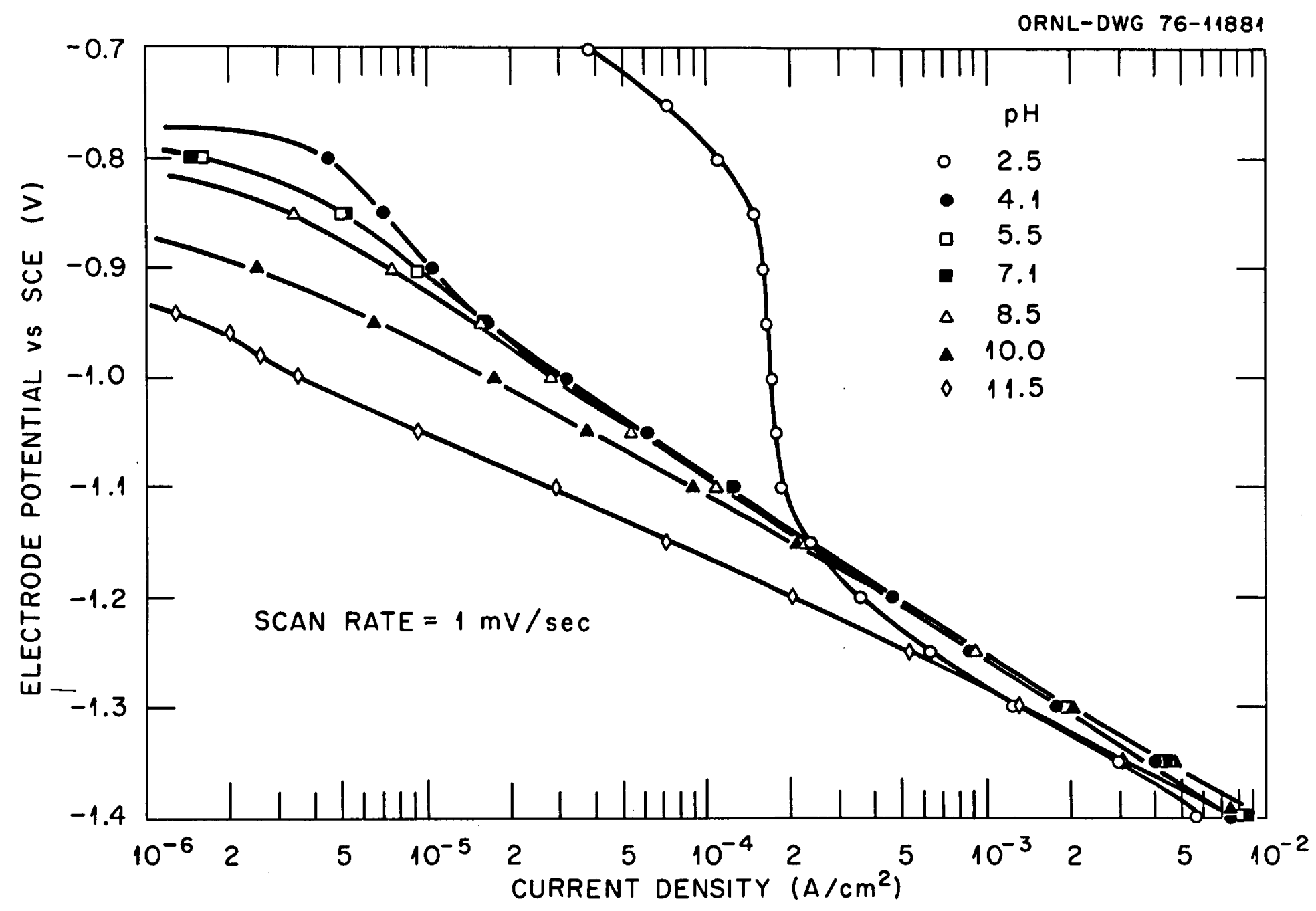

Fig. 3. Effect of pH on Cathodic Polarization of Iron in Deaerated $4 \mathrm{M} \mathrm{NaCl}, 25^{\circ} \mathrm{C}$. 
hydrogen ions, and the process is independent of $\mathrm{pH}$ over the region from approximately 5 to 9 . In more alkaline solutions, a decrease in the rate of the hydrogen evolution reaction is observed at any given electrode potential, along with a change in the slope of the cathodic polarization curve. The three regions of behavior observed in these results correspond to the regions seen in the plot of corrosion potential vs pH (cf. Fig. 1).

Some corresponding anodic polarization curves for the iron dissolution reaction as a function of $\mathrm{pH}$ are shown in Fig. 4. In acid solutions, the rate of the anodic process at a constant electrode potential increases with $\mathrm{pH}$. In neutral solutions, the rate is essentially independent of $\mathrm{pH}$, and in alkaline solutions the rate decreases with increasing $\mathrm{pH}$. The anodic and cathodic polarization curves, which are simply plots of the rates of these reactions as a function of electrode potential, together with their respective $\mathrm{pH}$ dependencies, determine the behavior of the corrosion system. As in any corrosion system, the intersection of the anodic and cathodic polarization curves determines both the spontaneous corrosion rate and the spontaneous corrosion potential. In the iron system in acid solution, although the specific rate of the iron dissolution reaction increases with $\mathrm{pH}$, the specific rate of the cathodic hydrogen evolution reaction more than compensates for this by its much more pronounced decrease with increasing $\mathrm{pH}$. The net effect is a decrease in the spontaneous corrosion rate of the iron system with increasing $\mathrm{pH}$ in the acid region (cf. Fig. 2). Once the influences of $\mathrm{pH}$ and chloride ion concentration on the rates of the anodic and cathodic processes on iron and carbon steel have been established as a function of temperature, it will then be possible to investigate the effects of other major and minor brine components on the rates of these reactions.

REACTIONS OF $\mathrm{Fe}$ (II) AND Fe(III) IN DEAERATED 4 M NaCl BELOW $100^{\circ} \mathrm{C}$

$$
\text { Reduction of } \mathrm{Fe}(\mathrm{II}) \text { on Iron }
$$

In addition to investigating the kinetics of the individual processes which are important in corrosion by electrochemical means, one may also study reactions of various components which are present in brines, either to establish their possible effects on corrosion itself, or to try to 


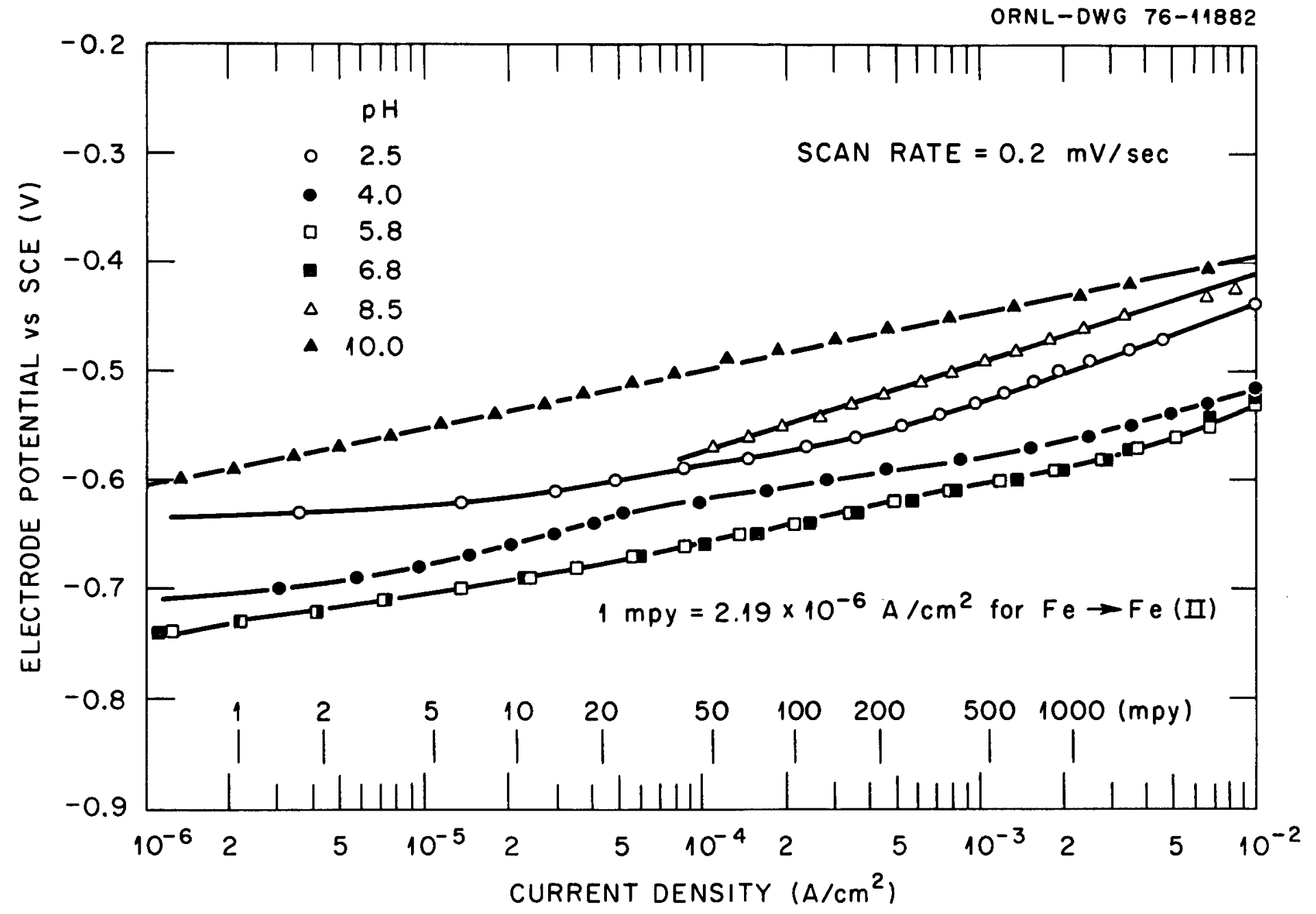

Fig. 4. Effect of $\mathrm{pH}$ on Anodic Polarization of Iron in Deaerated $4 \mathrm{M} \mathrm{NaCl}, 25^{\circ} \mathrm{C}$. 
elucidate their behavior under various plant operating conditions. For example, the oxidation and reduction behavior of dissolved iron in deaerated $4 \mathrm{M} \mathrm{NaCl}$ at $25^{\circ} \mathrm{C}$ has been investigated. Iron is a major component of some of the hypersaline brines in the Salton Sea region of California's Imperial Valley, where it is present in some cases at a concentration level up to $2000 \mathrm{ppm}$ (e.g., Niland brine). The reduction behavior of various amounts of ferrous ions on iron in deaerated $4 \mathrm{M} \mathrm{NaCl}$ solution at $\mathrm{pH} 4$ and $25^{\circ} \mathrm{C}$ is shown in Fig. 5 . Shown in Fig. 5 is a "background" curve for the hydrogen evolution reaction on iron with no ferrous ions present, and also cathodic polarization curves for three different concentrations of ferrous ions, including $2000 \mathrm{ppm}$. Formation of a black, porous layer is observed on the electrode surface at the lower potentials. Growth of this layer during the cathodic sweep decreases the limiting current for convective diffusion of ferrous ions to the electrode surface. This film, which is probably a form of ferrous hydroxide, is formed because hydroxide ions are produced at the interface as a product of the hydrogen evolution reaction and increase the interfacial $\mathrm{pH}$ enough to precipitate ferrous hydroxide, especially at the lower electrode potentials. It is noteworthy that, even at the $2000 \mathrm{ppm}$ level, the rate of reduction of ferrous ions in the region of the spontaneous corrosion potential of iron or low carbon steel (approx. $-750 \mathrm{mV}$ vs SCE in the neutral region), is not sufficient to affect the corrosion rate appreciably. From an experimental standpoint this means that soluble ferrous ion corrosion products may be allowed to accumulate in the test vessel to some extent without significant effect on the spontaneous corrosion rate.

Oxidation of $\mathrm{Fe}(\mathrm{II})$ and Reduction of $\mathrm{Fe}$ (III) on Pyrolytic Graphite

Results of some experiments on oxidation of ferrous ions and reduction of ferric ions on an inert, pyrolytic graphite electrode in deaerated $4 \underline{M}$ $\mathrm{NaCl}$ at $25^{\circ} \mathrm{C}$ are shown in Fig. 6 . Obviously, these reactions cannot be investigated with an iron electrode because of its enormous corrosion rate at these high potentials, so use of an inert electrode is necessary. The results shown in Fig. 6 are drawn from two different sets of experiments. In one set the anodic oxidation of $10^{-2} \underline{M} \mathrm{Fe}$ (II) was measured as a function of $\mathrm{pH}$, and in the other set the cathodic reduction of $\mathrm{Fe}$ (III), also 


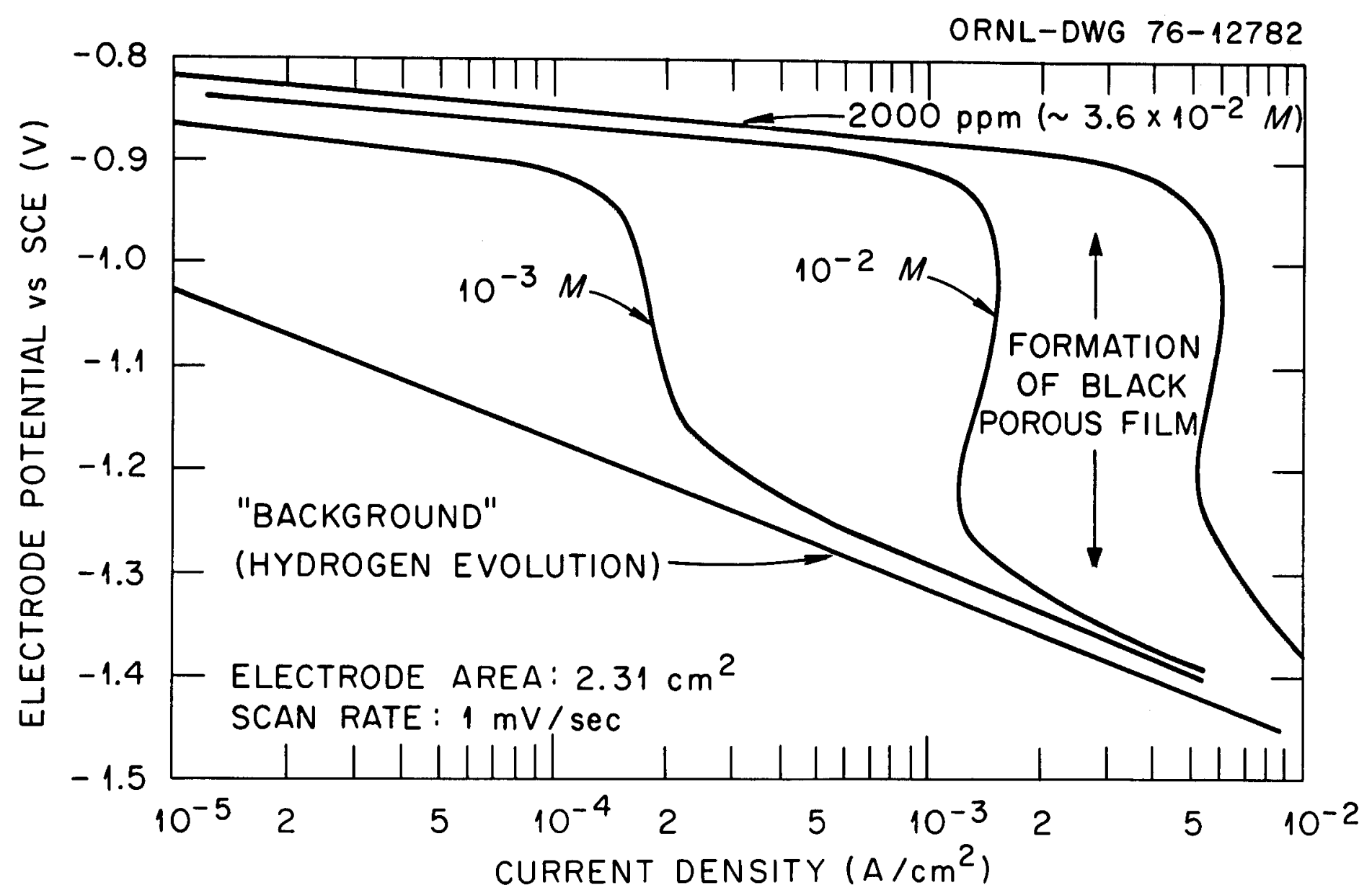

Fig. 5. Reduction of Fe(II) on Iron in Deaerated $4 \underline{\mathrm{M}} \mathrm{NaCl}, \mathrm{T}=25^{\circ} \mathrm{C}, \mathrm{pH}=4.0$. 


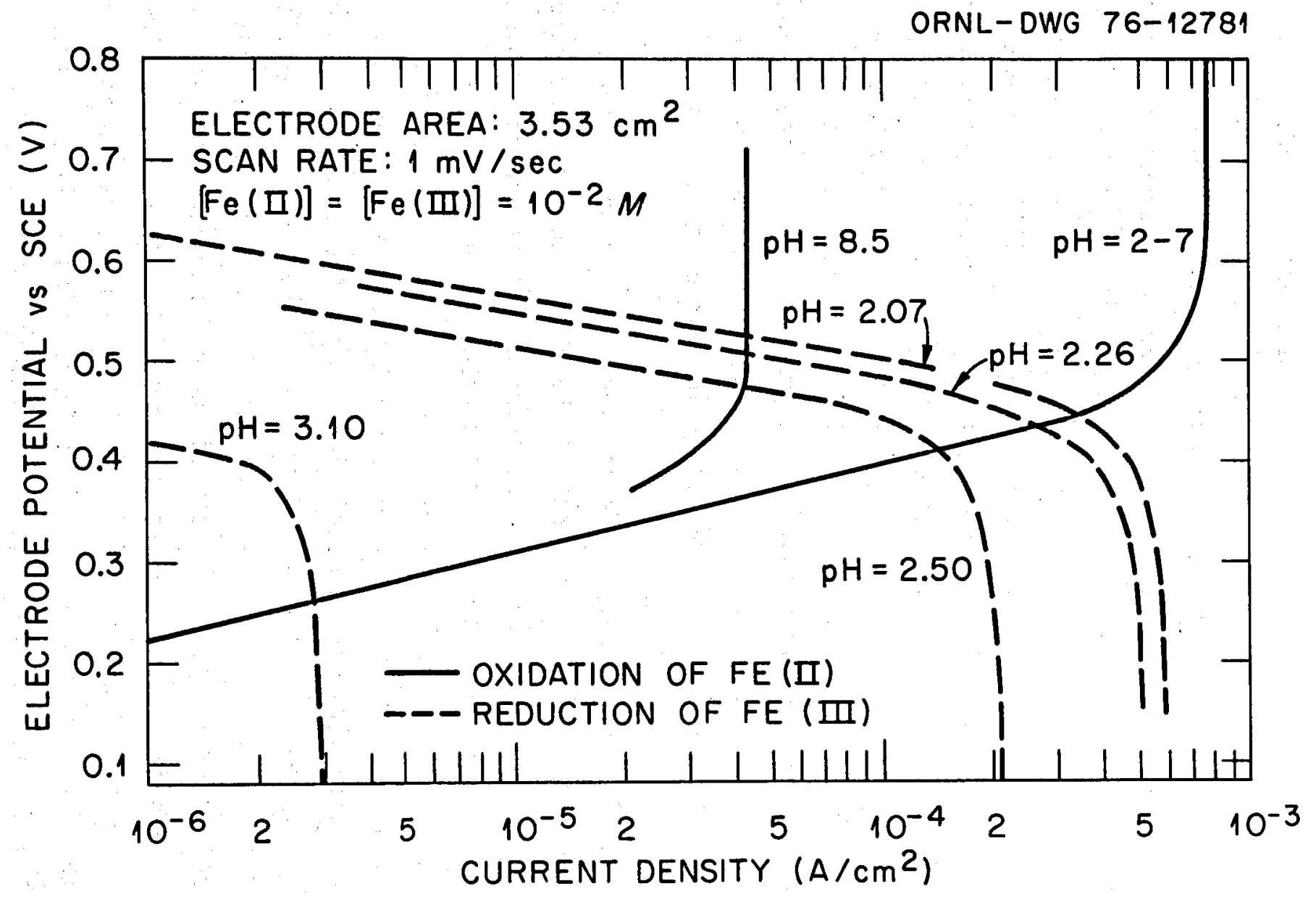

Fig. 6. Effect of $\mathrm{pH}$ on 0xidation of $\mathrm{Fe}(\mathrm{II})$ and Reduction of $\mathrm{Fe}$ (III) on Pyrolytic Graphite in $4 \mathrm{M}$ $\mathrm{NaCl}$ at $25^{\circ} \mathrm{C}$. 
present at a concentration of $10^{-2} \underline{\mathrm{M}}$, was measured as a function of $\mathrm{pH}$. Results of both sets of measurements are plotted in Fig. 6. The oxidation of ferrous ions is independent of $\mathrm{pH}$ up to at least $\mathrm{pH} 7$, al though further increase in $\mathrm{pH}$ causes precipitation of ferrous hydroxide and, consequently, a decrease in the reaction rate. On the other hand, the reduction of ferric ions in brine is exceedingly sensitive to $\mathrm{pH}$ even in rather acid solutions. As seen in Fig. 6, small changes in $\mathrm{pH}$ produce significant effects upon reaction rate, with corresponding changes in the visible appearance of the solution, as the $\mathrm{pH}$ increases from 2 to 3 . At any given $\mathrm{pH}$ the polarization curve for reduction of $\mathrm{Fe}$ (III) intersects the polarization curve for oxidation of $\mathrm{Fe}$ (II) at the apparent reversible potential of the $\mathrm{Fe}$ (II)-Fe(III) couple in this medium. Thus the apparent reversible potential decreases with increasing $\mathrm{pH}$ primarily because of hydrolys is of $\mathrm{Fe}$ (III) species, with resulting decrease in the activity of the oxidant. One may surmise that the measurement with an inert electrode of the "redox potential" of brines containing large amounts of ferrous ions will be exceedingly sensitive to the inleakage of atmospheric oxygen to the measuring electrode.

These results imply that any ferric ions that are produced by whatever means in these brines will certainly be hydrolyzed and precipitated and will not function as a cathodic reactant at the higher $\mathrm{pH}^{\prime} \mathrm{s}$ which are normally encountered in geothermal brines. So, in this sense, the large amount of ferrous ions found in some hypersaline brines acts as a redox buffer to maintain reducing conditions in the plant as long as it is operating properly without too much inleakage of atmospheric oxygen or other oxidizing agents. However, there is a further, much more insidious implication in these observations. Suppose that a plant is normally operating on a Niland-type brine, containing a large concentration of $\mathrm{Fe}(\mathrm{II})$, and then for some reason the plant must be shut down. If the brine is not drained from the plant and if atmospheric oxygen is allowed access to the brine, the large amount of ferrous ions will be oxidized to ferric ions by oxygen inleakage. Then the ferric ions will quickly hydrolyze, producing large amounts of hydrogen ions. Simple stoichiometry shows that two hydrogen ions can be produced for each ferrous ion which is hydrolyzed. Consequently, if the reaction went to completion, approximately 
$7 \times 10^{-2} \mathrm{M} \mathrm{H}^{+}$could be produced from $2000 \mathrm{ppm} \mathrm{Fe}(\mathrm{II})$, resulting in an enormous increase in the acidity of the brine and thus also in the corrosion rate of the carbon steel containment material, perhaps by a factor of a thousand or more (cf. trends in Fig. 2). Also, ionic activity coefficients are very high in concentrated brines, and the effective acidity will be much higher than that calculated from simple stoichiometry.

These results imply that great caution should be exercised during shutdown of a geothermal plant. Either the plant should be drained and rinsed, or perhaps a protective blanket of inert gas should be employed to exclude atmospheric oxygen from stagnant brine, much as was found to be necessary in desalting practice. In subsequent measurements, data of the same general type as that shown in Fig. 6 will be obtained at elevated temperatures. This type of information on oxidation-reduction reactions of brine components is relatively easy to obtain by electrochemical means, but may be considerably more difficult to obtain by more conventional methods.

\section{PITTING OF 304 STAINLESS STEEL IN SYNTHETIC BRINE BELOW $100^{\circ} \mathrm{C}$}

\section{Current Transients at Constant Electrode Potential}

During FY1976 some measurements were carried out on the pitting behavior of type 304 austenitic stainless steel in a deaerated $4 \mathrm{M} \mathrm{NaCl}$ solution or a simple synthetic brine $\left(2.34 \underline{\mathrm{M} \mathrm{NaCl}}+0.68 \mathrm{M} \mathrm{CaCl}_{2}+0.41 \mathrm{M}\right.$ $\mathrm{KCl})$ as a function of temperature. Since the measurements were made in the conventional Pyrex test cell, it was not possible to investigate temperatures much in excess of $85^{\circ} \mathrm{C}$. Information of this type may be useful in brine applications because an upper limit exists on the allowable electrode potentials of stainless steel in chloride solutions without undue risk of catastrophic pitting attack. This limit is known as the pitting potential.

Initially, a procedure was followed of allowing the stainless steel electrode to attain a steady state under potentiostatic control at some standardized potential below the pitting potential, and then suddenly changing the electrode potential to some more noble value. If the final 
electrode potential was more positive than the pitting potential, a current transient such as that shown in Fig. 7 was observed. This behavior is typical of many metals which are subject to pitting attack; a review of various aspects of pitting of metals may be found in the book by Kaesche. ${ }^{19}$ The first part of the transient (cf. Fig. 7) consists of current decay due principally to a change in the thickness of the passive oxide layer on the electrode surface. The time required to initiate a pit on the electrode surface depends upon the difference between the final electrode potential and the pitting potential. Subsequently, the current increases with time in a manner which depends upon the kinetics of pit growth at constant electrode potential and the rate of nucleation of new pits on the electrode surface. Our observations of this type on the kinetics of pit growth were found to be consistent with work carried out earlier in less concentrated chloride solutions, but these measurements proved to be somewhat unsatisfactory for establishment of the pitting potential. Subsequent measurements were concerned with observations on potential transients on stainless at constant applied anodic current.

Potential Transients at Constant Applied Anodic Current

Some electrode potential transients observed durina application of several values of constant applied anodic current to a type 304 stainless steel electrode in simple synthetic brine are shown in Fig. 8 . During the early stages of the galvanostatic transients, anodization of the passive oxide layer takes place with increase in the film thickness (at constant field strength within the oxide layer) until penetration of the film by chloride ions and formation of a pit. Upon formation of pits the electrode potential falls rapidly and is subsequently determined by the pit growth process. The electrode potential finally stabilizes at a value which is taken to be the pitting potential. The same final electrode potential is established (approximately) by the specimen regardless of the magnitude of the applied anodic current over wide limits. The pitting potential signifies the electrode potential which must not be approached very closely or exceeded in the medium in question without the occurrence of pitting attack and resultant catastrophic metal wastage. 


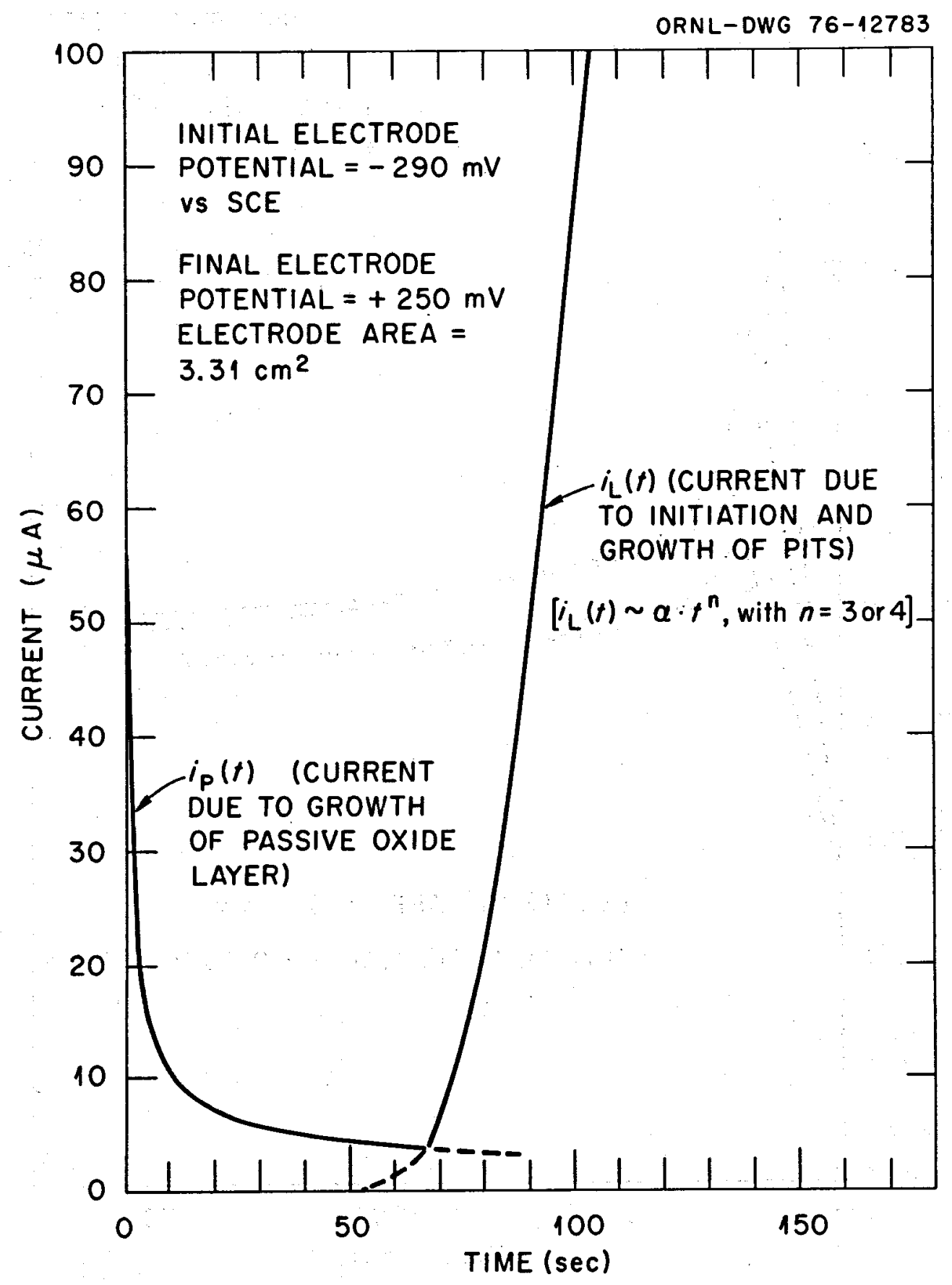

Fig. 7. Current Transient for Pit Initiation and Growth on 304 Stainless Steel at Constant Electrode Potential in Deaerated $4 \mathrm{M} \mathrm{NaCl}, \mathrm{T}=25^{\circ} \mathrm{C}$, $\mathrm{pH}=8$. 


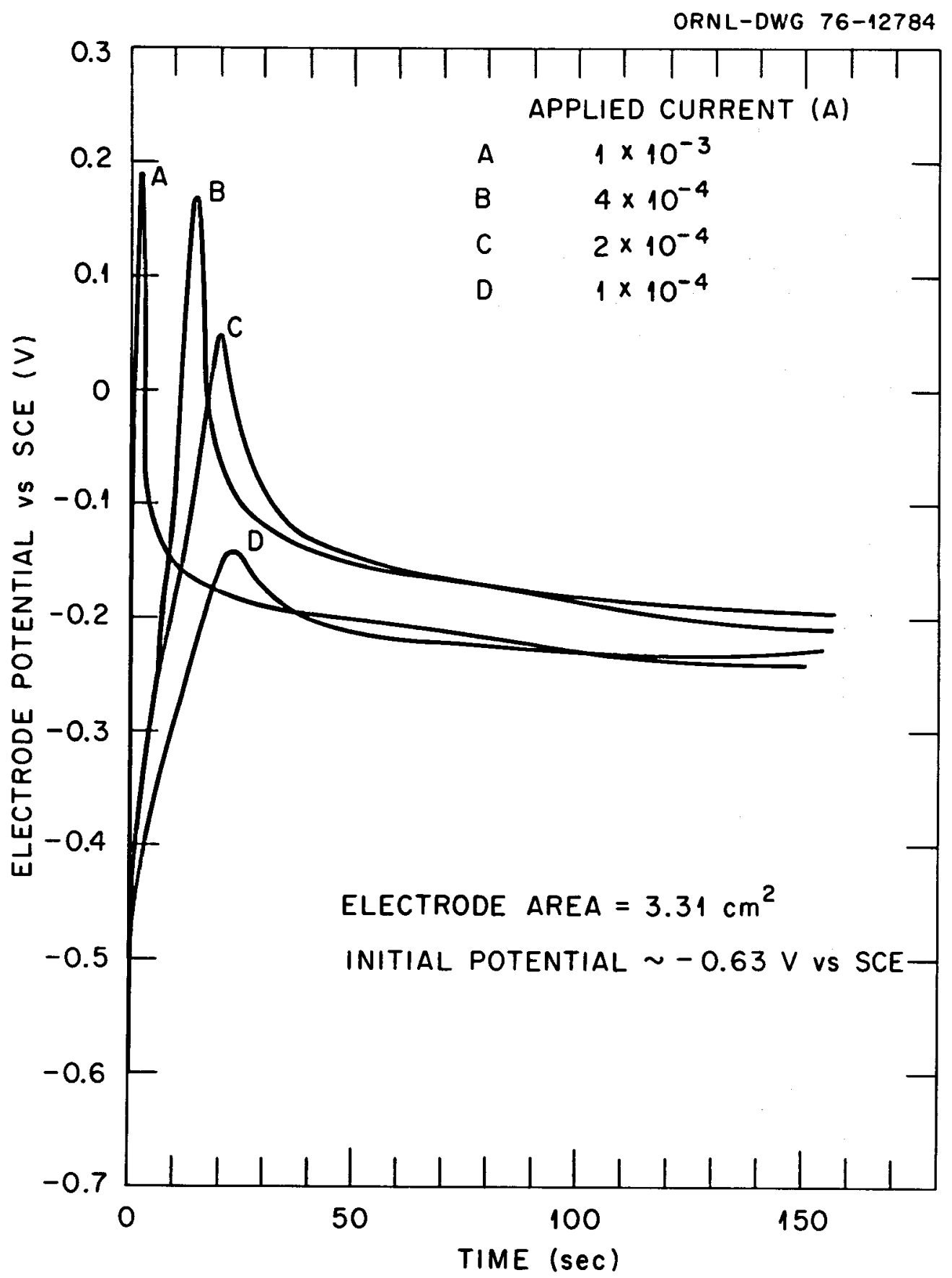

Fig. 8. Potential Transients for Pit Initiation and Growth on 304 Stainless Steel at Constant Applied Anodic Current in Deaerated Synthetic Brine (2.34 M $\mathrm{NaCl}+0.68 \underline{\mathrm{M} \mathrm{CaCl}} 2+0.41 \underline{\mathrm{M} \mathrm{KCl}}), \mathrm{T}=45^{\circ} \mathrm{C}, \mathrm{pH}=\frac{\mathrm{MH}}{4} .4$. 
Variation of Pitting Potential with Temperature

Experimentally observed values of the pitting potential of type 304 stainless steel in synthetic brine, determined by the procedure indicated in Fig. 8, are shown in Fig. 9 as a function of temperature from $25^{\circ}$ to $85^{\circ} \mathrm{C}$. These data may be compared with some earlier measurements by Leckie and $\mathrm{Uhlig}^{20}$ in $0.1 \mathrm{M} \mathrm{NaCl}$ solution. The stainless steel pits at significantly lower potentials in strong brine than in weaker chloride solutions, and the pitting potential decreases further with increase in temperature. The results of these measurements (and other previous observations) suggest that, al though stainless steel corrodes spontaneously at an extremely low rate (fractions of a mil per year) in deaerated brine, traces of oxidizing agents could suffice to raise the electrode potential to the pitting potential, resulting in rapid corrosion and penetration. This observation is also in agreement with previous experience in the use of stainless steels in seawater service. One should remember, moreover, that stress corrosion cracking of the austenitic stainless steels also occurs in oxygen-containing chloride environments.

\section{REFRESHED, STIRRED TITANIUM AUTOCLAVE SYSTEM FOR STUDIES ABOVE $100^{\circ} \mathrm{C}$}

Much of the effort during FY1976 was devoted to design, construction, and testing of a refreshed, stirred titanium autoclave system for carrying out electrochemical measurements up to at least $200^{\circ} \mathrm{C}$, and possibly to $250^{\circ} \mathrm{C}$. A schematic diagram of the system is shown in Fig. 10. The stock solution (approx. 50 liters) of synthetic brine to be injected into the autoclave assembly is partially deaerated by sparging with argon. This solution is then pumped to the top of a deaeration column (length $\sim 120 \mathrm{~cm}$ ) and back to the reservoir so that the column is kept full. Solution entering the autoclave must travel down through the deaeration column, countercurrent to a stream of fine argon bubbles, before a diaphragm pulse pump (capacity $\sim j \mathrm{liter} / \mathrm{hr}$ ) forces it into the autoclave. A pressure gauge and a 1000 psi safety relief valve (rupture disk) are located between the pump and the autoclave. The temperature of the 


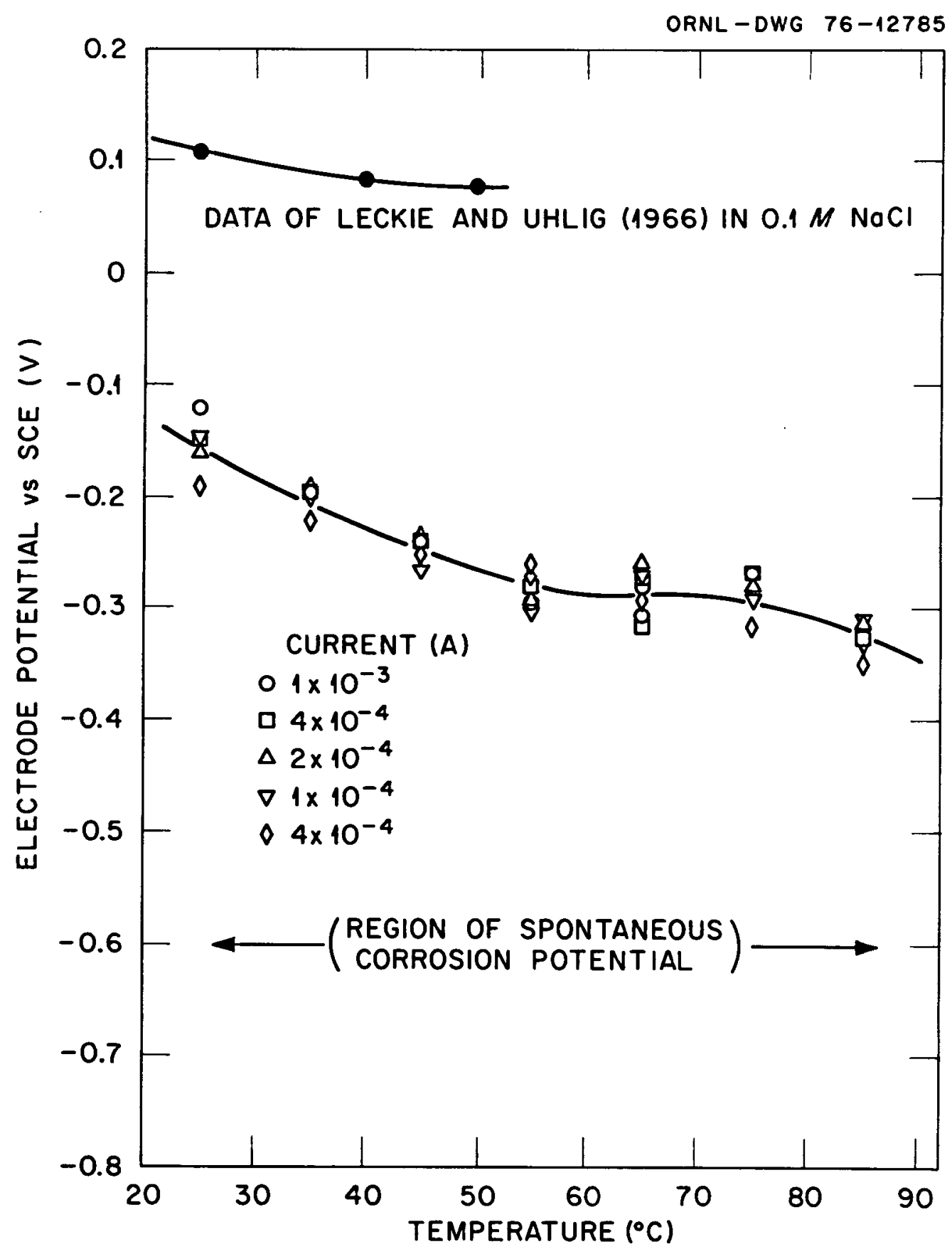

Fig. 9. Variation of Pitting Potential with Temperature for 304 Stainless Steel in Deaerated Synthetic Brine $(2.34 \underline{\mathrm{M} \mathrm{NaCl}}+0.68 \underline{\mathrm{M} \mathrm{CaCl}} 2+0.41 \underline{\mathrm{M}}$ $\mathrm{KCl}$ ); $\mathrm{pH}$ Range: $3-6$. 
ORNL- OWG 76-11287

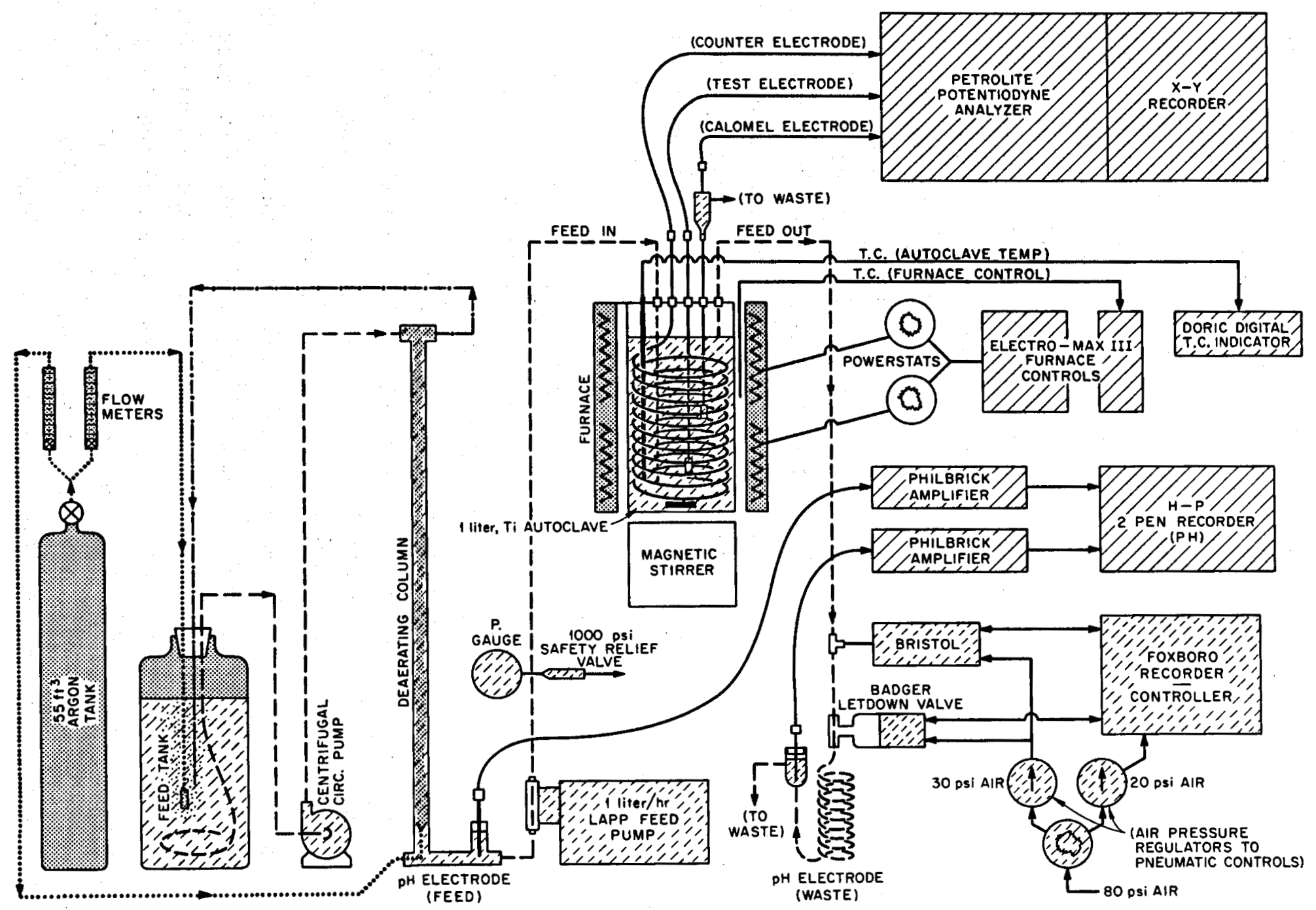

Fig. 10. Schematic Diagram of Refreshed, Stirred Titanium Autoclave System for Electrochemical Studies. 
autoclave is controlled by a surrounding furnace which is regulated by an automatic electronic temperature controller; the temperature inside the autoclave is monitored on a digital temperature indicator. Since the autoclave is constructed from titanium, it is possible to use a conventional Teflon-covered magnetic stirring bar inside the autoclave for stirring of the solution. Pressure inside the autoclave is maintained at any desired level (typically 200 - 500 psig) by a pneumatic letdown valve; the pressure is recorded continuously on a small stripchart recorder. The (room temperature) $\mathrm{pH}$ of the solution entering and leaving the autoclave is monitored on a strip-chart recorder.

A more detailed view of the titanium autoclave assembly is shown in Fig. 11. The autoclave, having a capacity of about 1 liter, has a wall thickness of approximately $2 \mathrm{~cm}$. The head shown at the bottom of Fig. 11 contains a working electrode assembly, a reference electrode assembly, titanium tubes for entry and egress of solution, and a titanium thermocouple well. Not shown in Fig. 11 is the counter electrode assembly which is a long coil of titanium wire wound on Teflon spacers for insulation from the other autoclave components (cf. Fig. 10). The electrode holder and contact rod is a Teflon-covered titanium rod to which the iron or steel cylindrical electrode is attached with use of a Teflon compression gasket, according to the design suggested by Agarwal, Damin, Mccright, and Staehle. ${ }^{21}$ The reference electrode assembly is a modification of the design published by wilde, ${ }^{22}$ which allows pressure drop to be absorbed in a compressible fiberglass plug which allows a small, controlled leak rate of electrolyte into an external reference electrode compartment maintained at room temperature.

An overall view of the experimental assembly is shown in Fig. 12. The furnace was removed from around the autoclave assembly to reveal more clearly the components of the system. The system is mounted on a moveable test rig, with instruments and pressure gauges located on the front panel (at the left side of Fig. 12). The autoclave sits on top of a conventional magnetic stirrer on the upper shelf with the diaphragm pulse pump located on the lower shelf. Figure 13 is a view from the opposite side showing the stock solution reservoir on the lower shelf, some of the pneumatic pressure-controlling apparatus attached to the front panel, and 


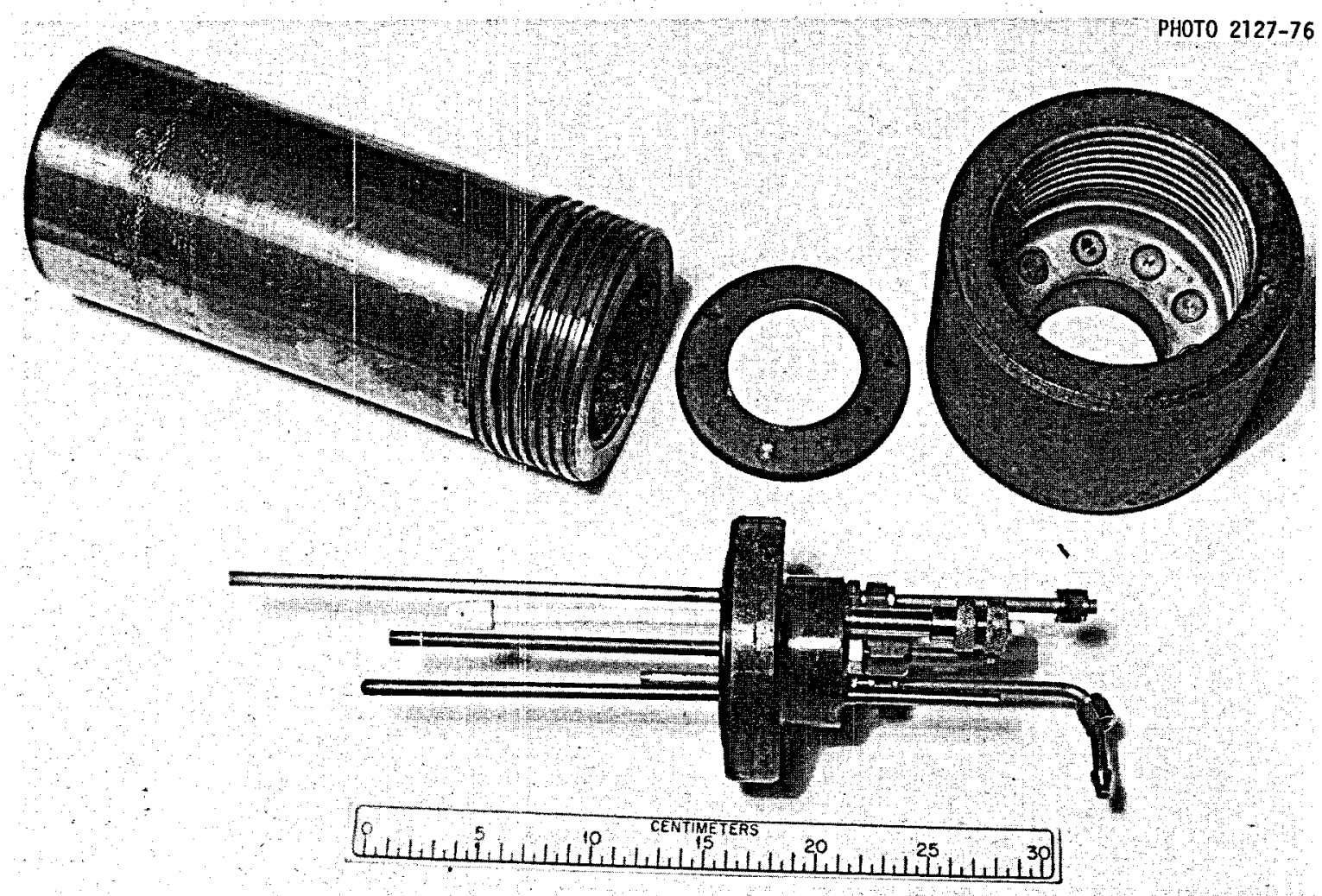

Fig. 11. View of Disassembled Titanium Autoclave. 


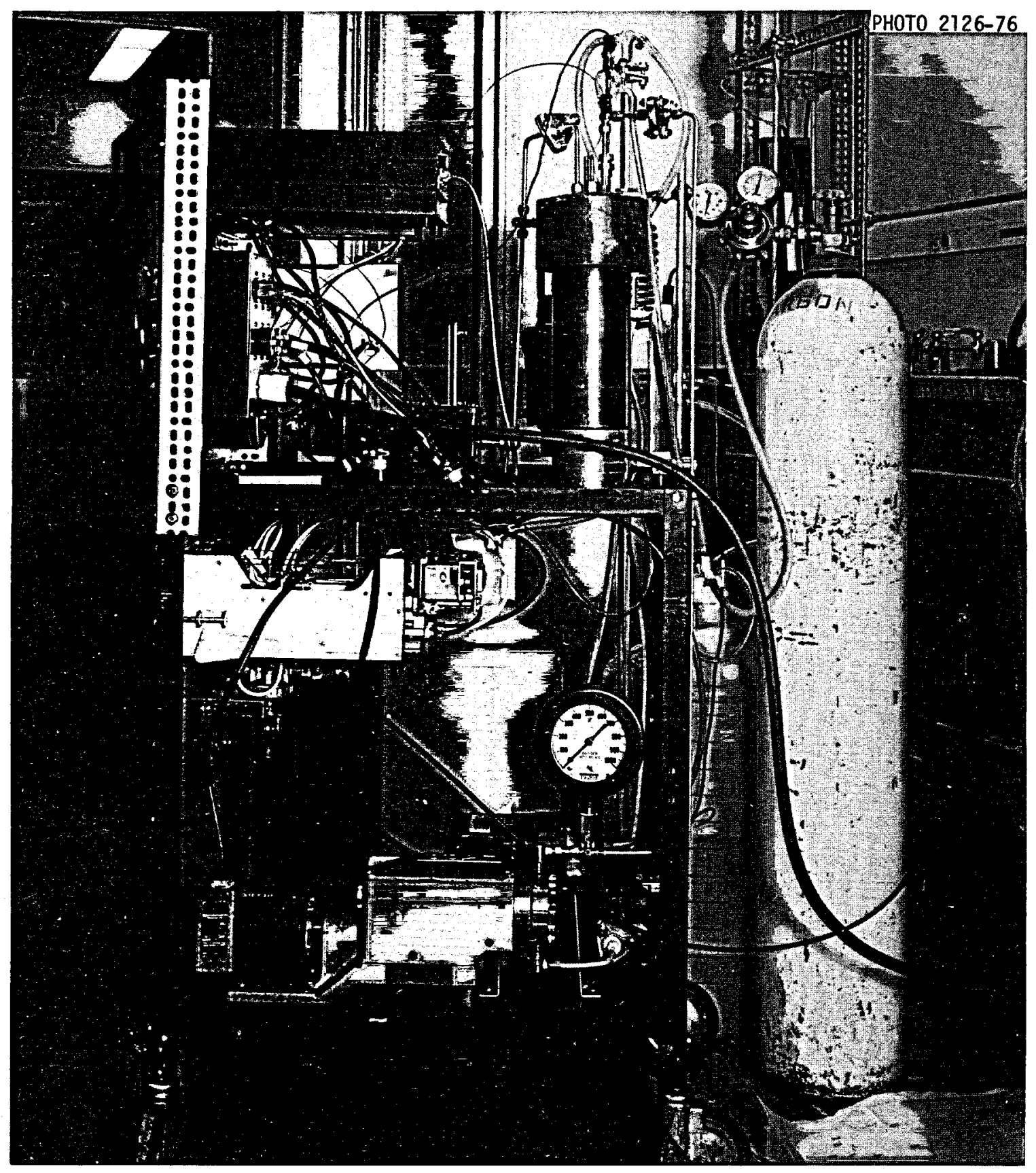

Fig. 12. Right Side View of Titanium Autoclave System. 


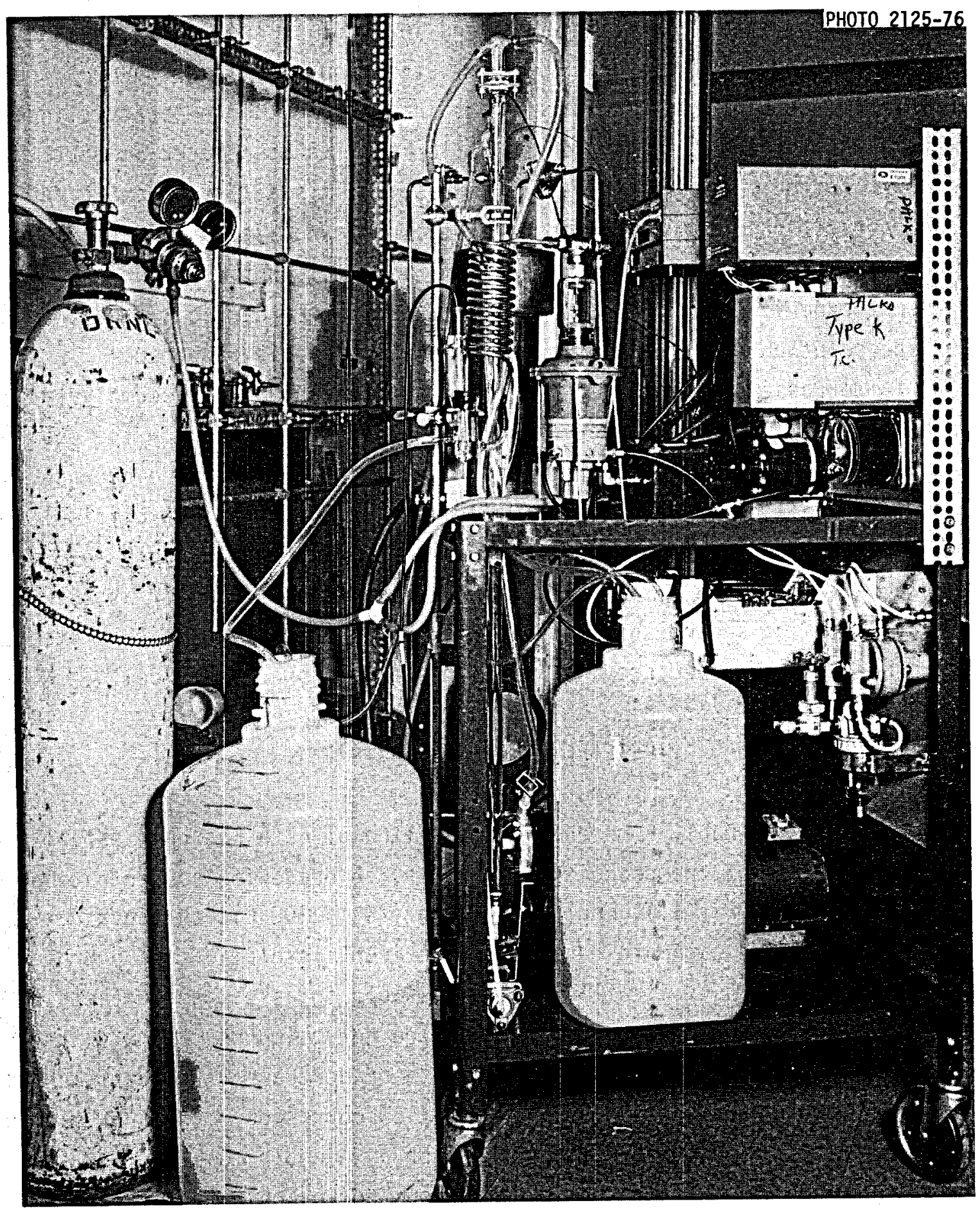

Fig. 13. Left Side View of Titanium Autoclave System. 
the letdown valve situated on the upper shelf. The top of the deaeration column may be seen projecting above and in front of the autoclave assembly at the center of the picture. Finally, the front panel is shown at the right side of Fig. 14. The panel contains the digital temperature indicator, the furnace temperature controller and its associated powerstats, a power switch panel, air pressure gauges, and a small strip-chart recorder for continuous monitaring of the pressure within the autoclave. The instrumentation on the left side of Fig. 14 is not used for the present experiments except for the strip-chart recorder, on which the pH of the solution entering and leaving the autoclave is recorded.

After assembly of the complete system, the autoclave assembly was pressure tested on both water and $4 \underline{M ~ N a C l}$ solution to verify the operation of both the test electrode assembly and the reference electrode assembly. All components worked well after some ground-loop difficulties encountered in use of the electrochemical instrumentation had been corrected. Preliminary measurements, carried out in $4 \mathrm{M} \mathrm{NaCl}$ at $25^{\circ} \mathrm{C}$ and about 200 psig, showed substantially the same behavior for carbon steel that had been observed previously in the conventional Pyrex cell.

\section{RESEARCH PLANS FOR FY1977}

Once a reasonably comprehensive baseline of data has been established for the effects of the principal variables, chloride ion concentration $(0.1-4 \underline{M}), \mathrm{pH}(3-11)$, and temperature $\left(25^{\circ}-200^{\circ} \mathrm{C}\right)$, on the kinetics of the anodic and cathodic reactions (the iron dissolution and hydrogen evolution reactions), it will then be possible to assess the effects of the major and minor brine components on the corrosion reactions. It should be noted that some major components of geothermal brines, such as potassium ion, may exert a minimal effect on corrosion rates, while some relatively minor or trace components, such as a noble metal or sulfide, may exert enormous effects on instantaneous corrosion rates, on the constitution and morphology of corrosion products, and on the long-term corrosion behavior. Therefore, it is necessary to investigate these effects in a sequential manner, starting with the simpler systems and then proceeding to the more complex. 


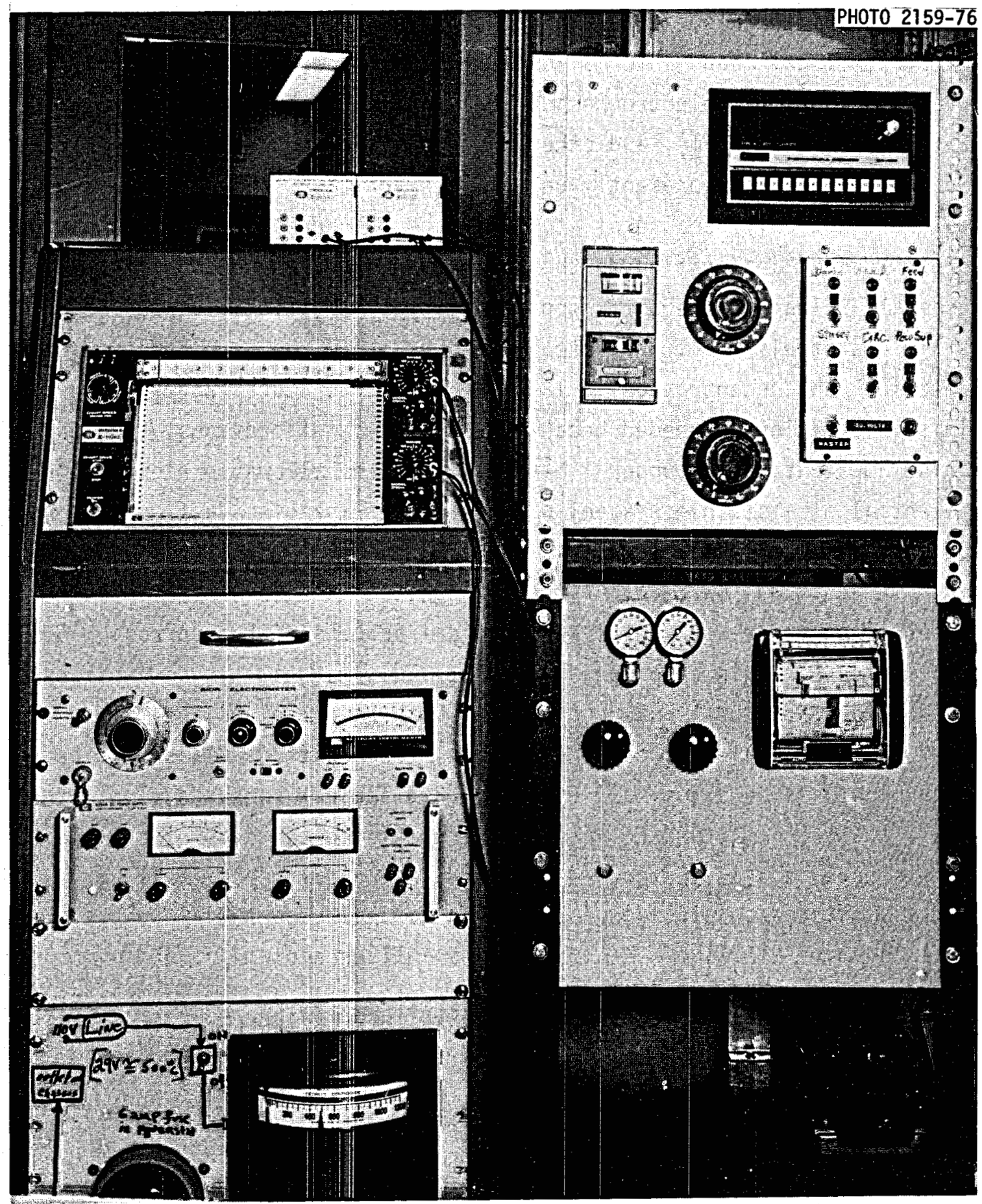

Fig. 14. View of Control Panels for Titanium Autoclave System. 
In addition to effects of brine constitutents on corrosion reactions of ferrous materials, it is also possible and desirable to obtain by electrochemical means information on the influence of $\mathrm{pH}$ on hydrolysis, precipitation, and electrochemical reactivity of substances such as $\mathrm{Fe}(\mathrm{II}), \mathrm{Mn}$ (II), $\mathrm{Pb}$ (II), and other oxidizable or reducible soluble ions. Such information is presently unavailable from any source and will be valuable not only because of its relevance to corrosion but also because of its direct application to the understanding of brine chemistry in general. Finally, the pitting potentials of some typical austenitic stainless steels $(304,316$, etc.) will be determined as a function of chloride ion concentration $(0.1-4 \underline{M})$ and temperature $\left(25^{\circ}-200^{\circ} \mathrm{C}\right)$. This information is needed because, as pointed out previously, in possible brine applications an upper limit exists on the allowable electrode potential of a stainless steel without undue risk of catastrophic pitting attack.

In addition to the experimental work, it will be useful to carry out a survey of prior work on electrochemical aspects of the corrosion of iron and carbon steel in chloride solutions. This material is somewhat difficult to collect, but should be useful, both to ourselves and to other workers, as a basis for comparison and interpretation. It should be possible to issue a topical report on this subject rather early in the year. Later on, after the data on the pitting potentials of stainless steels have been collected and analyzed, a topical report will be issued. Finally, at the conclusion of FY1977, a topical report will be prepared which summarizes all of the work on the influence of major and minor brine constituents on the corrosion of iron and steel in simulated geothermal brines. 


\section{REFERENCES}

1. D. W. Shannon, Economic Impact of Corrosion and Scaling Problems in Geothermal Energy Systems, BNWL-1866 (January, 1975).

2. B. Kabanov, R. Burstein, and A. Frumkin, Disc. Faraday Soc. 1, 259 (1947).

3. A. Rius and R. Lizarbe, Electrochim. Acta 7,513 (1962).

4. K. Nobe and R. F. Tobias, Corrosion 20, 263 (1964).

5. K. Venu, K. Balakrishnan, and K. S. Rajagopalan, Corros. Sci. $\underline{5}$, 59 (1965).

6. W. J. Lorenz, Corros. Sci. 5, 121 (1965).

7. J. J. Podesta and A. J. Arvia, Electrochim. Acta 10, 171 (1965).

8. L. Felloni, Corros. Sci. 8,133 (1968).

9. A. J. Arvia and J. J. Podesta, Corros. Sci. 8, 203 (1968).

10. R. T. Foley, Corrosion 26, 58 (1970).

11. W. J. Lorenz and G. Eichkorn, Ber. Bunsenges. physik. Chem. 므, 99 (1966).

12. S. Asakura and K. Nobe, J. Electrochem. Soc. 118, 13 (1971).

13. S. Asakura and K. Nobe, J. Electrochem. Soc. 118, 19 (1971).

14. R. J. Chin and K. Nobe, J. Electrochem. Soc. 119, 1457 (1972).

15. N. A. Darwish, F. Hilbert, W. J. Lorenz, and H. Rosswag, Electrochim. Acta 18, 421 (1973).

16. M. A. LaBoda and M. L. McMillan, Electrochem. Technol. $\underline{5}, 340$ (1967).

17. D. T. Chin, J. Electrochem. Soc. 118, 174 (1971).

18. H. C. Kuo and D. Landolt, Electrochim. Acta 20, 393 (1975).

19. H. Kaesche, Die Korrosion der Metalle, Physikalisch-chemische Prinzipien und aktuelle Probleme, p. 251, Springer Verlag, Berlin, 1966.

20. H. P. Leckie and H. H. Uhlig, J. Electrochem. Soc. 113, 1262 (1966).

21. A. K. Agrawal, D. C. Damin, R. D. McCright, and R. W. Staehle, Corrosion 31, 262 (1975).

22. B. E. Wilde, Corrosion 23, 331 (1967). 

ORNL/TM-5688

Dist. Category UC-4

\section{INTERNAL DISTRIBUTION}

\author{
1. A. L. Bacarella \\ 2. J. Blevins, ORO \\ 3. E. G. Bohlmann \\ 4. J. H. DeVan \\ 5. L. M. Ferris \\ 6. J. C. Griess \\ 7. 0. L. Keller \\ 8. E. J. Kelly \\ 9. R. N. Lyon \\ 10. W. R. Martin \\ 11. R. E. Mesmer \\ 12. R. E. Meyer \\ 13. J. W. Michel
}

\author{
14. A. A. Palko \\ 15-34. F. A. Posey \\ 35. H. Postma \\ 36. M. W. Rosenthal \\ 37. I. L. Thomas \\ 38. J. R. Weir \\ 39. A. Zucker \\ 40-41. Central Research Library \\ 42. ORNL Patent Office \\ 43. ORNL-Y-12 Technical Library, \\ Document Reference Department \\ 44. Laboratory Records, ORNL, RC \\ 45-46. Laboratory Records Department
}

\section{EXTERNAL DISTRIBUTION}

47. Director of Research and Technical Support Division, ERDA-ORO

48. M. J. Danielson, Battelle Pacific Northwest Laboratories, Battelle Blvd., Richland, WA 99352

49. R. P. Epple, Division of Physical Research, ERDA, Washington, DC 20545

50. A. Goldberg, Lawrence Livermore Laboratory, P. 0. Box 808, Livermore, CA 94550

51. J. E. Harrar, Lawrence Livermore Laboratory, P. 0. Box 808, Livermore, CA 94550

52. D. E. Michels, Aerojet Nuclear Co., 550 Second St., Idaho Falls, ID 83401

53. P. B. Needham, Bureau of Mines, U. S. Dept. of Interior, College Park, MD 20740

54. H. H. Paalman, Research Laboratories, Dow Chemical U.S.A., 2800 Mitchel1 Drive, Walnut Creek, CA 94598

55-59. R. R. Reeber, Division of Geothermal Energy, ERDA, 20 Massachusetts Ave., Washington, DC 20545

60. D. W. Shannon, Battelle Pacific Northwest Laboratories, Battelle Blvd., Richland, WA 99352

61. B. C. Syrett, Stanford Research Institute, Ravenswood Ave., Menlo Park, CA 94025

62-247 Given distribution per TID 4500, Chemistry Category UC-4 (25 copies, NTIS) 